\title{
PEMIKIRAN FIKIH MUHAMMAD ASYWADIE SYUKUR
}

\author{
Abdul Helim \\ Institut Agama Islam Negeri Palangka Raya \\ Jl. Menteng, Kec. Jekan Raya, Kota Palangka Raya, Kalimantan Tengah, 73112 \\ e-mail: helim1377@gmail.com
}

\begin{abstract}
Abstrak: Artikel ini berupaya mengkaji pemikiran fikih Asywadie Syukur sebagai seorang ulama, akademisi dan sekaligus politisi. Pemikirannya meliputi tidak hanya terkait persoalan klasik tetapi juga persoalan kontemporer dan bahkan yang masih menjadi polemik di masyarakat, yang dihasilkan dari proses metodologis baik metode qaulî maupun metode manhajî. Dari proses inilah membuat Asywadie Syukur tidak terikat hanya pada satu mazhab tetapi terbuka pula pada mazhab yang lain. Namun karena referensi yang digunakan lebih dominan ke mazhab Syâfi'î, kecenderungan fikih pun identik ke mazhab Syâfiî̀ dengan tipologi tradisionalisme sekaligus neo-tradisionalisme bermazhab. Di sisi lain, Asywadie Syukur juga bermanhaj pada teori-teori kemaslahatan sehingga jika dikembalikan pada teori besar tipologi, disamping masuk dalam tipologi tradisionalisme ia juga masuk dalam tipologi modernisme.
\end{abstract}

\begin{abstract}
Islamic Legal Thought of Muhammad Asywadie Syukur. This article seeks to examine Islamic legal thought of Asywadie Syukur as a scholar, academician and politician. His works covers not only in the field of the classical perspective, but also related to contemporary issues. But whatever they are, its naturally produced through the methodological process using either a qaulî or manhajî method. Based on this process, Asywadie Syukur is not confined to one particular school of legal thought. However, due to the fact that the references used are predominantly that of Syâfi'î, the tendency of his thought is identical with the principles of the latter with a typology of traditionalism with neo-traditionalism as a consequences of madhhab follower. Consequently, Asywadie Syukur follows the theories of public interest so that if is referred to grand theory of typology, in addition to traditionalism typology he also engaged in modernism typology.
\end{abstract}

Kata Kunci: fikih, Asywadie Syukur, qaulî, manhajî, ushul fikih 


\section{Pendahuluan}

Pemikiran fikih merupakan bahasa lain dari metode penetapan hukum atau disebut pula usul fikih. ${ }^{1}$ Pemikiran fikih ini cenderung tidak terlihat eksplisit di berbagai kitab fikih, tetapi pendapat-pendapat itu tentu tidak mungkin muncul dengan tiba-tiba tanpa proses yang panjang. Dipastikan ada tahapan-tahapan yang dilakukan sampai akhirnya menjadi buah pikiran masing-masing ulama penulis kitab.

Salah satu yang menarik untuk dikaji adalah pendapat-pendapat Asywadie Syukur di berbagai karyanya, ${ }^{2}$ khususnya di bidang fikih, baik yang telah dibukukan ataupun yang masih dalam bentuk dokumen. Ada beberapa alasan pendapat-pendapat itu dipandang penting diteliti. Pertama, Asywadie Syukur termasuk sosok pribadi yang unik. Di samping sebagai ulama yang memiliki karya dan menjadi pengasuh acara Konsultasi Hidup dan Kehidupan di RRI Nusantara III Banjarmasin sejak tahun 1971 sampai tahun 1994, ia juga secara akademik pernah menjadi Rektor IAIN Antasari Banjarmasin, bahkan di dunia politik pernah menjadi anggota DPRD Tingkat I dan anggota MPR RI. Hal ini mengisyaratkan adanya integrasi berbagai kompetensi yang mungkin tidak dimiliki semua orang pada masa itu khususnya di Kalimantan Selatan. Hal lainnya ia cenderung diorientasikan sebagai seorang ulama tasawuf dan pemikiran. Anggapan ini terpatahkan karena ia juga memiliki karyakarya di bidang fikih bahkan latar belakang pendidikan dan guru besarnya pun di bidang fikih. ${ }^{3}$

Kedua, Asywadie Syukur dianggap netral ${ }^{4}$ dalam organisasi keagamaan sehingga tidak tercatat sebagai anggota dari organisasi Nahdhatul Ulama (NU), Muhammadiyah, Al Washliyah atau pun organisasi keagamaan lainnya kecuali di Majelis Ulama Indonesia (MUI) Kalimantan Selatan. ${ }^{5}$ Jika dikaitkan dengan pendapat-pendapatnya di bidang fikih maka sikap netral ini menjadi hal yang menarik untuk mengkaji pemikiran fikih Asywadie Syukur, termasuk pula tipologi dan kecenderungannya dalam berpendapat.

\footnotetext{
${ }^{1}$ Ushul fikih adalah kumpulan metode yang digunakan untuk menggali, menemukan dan menetapkan status hukum suatu persoalan. Pengertian serupa salah satunya lihat Abdul Wahhâb Khallâf, 'Ilm Ushûl al-Fiqh (Kuwait: Dâr al-Qalam, 1978), h. 12.

${ }^{2}$ Bayani Dahlan, et al., H.M. Asywadie Syukur Ulama Kampus dan Ulama Pembangunan (Banjarmasin: Antasari Press, 2007), h. 38-39 dan 56-59.

${ }^{3}$ Asywadie Syukur, Mode Ijtihad Masa Dulu dan Masa Kini (Banjarmasin: IAIN Antasari Banjarmasin, 1992).

${ }^{4}$ Dahlan, et al., H.M. Asywadie Syukur Ulama, h. 82-83.

5Ibid., h. 81. Tentang ormas Islam ini, lihat Khoirun Niam, "Nahdlatul Ulama and the Production of Muslim Intellectuals in the Beginning of 21st Century Indonesia," dalam Journal of Indonesian Islam, Vol. 11, No. 2, 2017; Masdar Hilmy. "Quo-Vadis Islam Moderat Indonesia? Menimbang Kembali Modernisme Nahdlatul Ulama dan Muhammadiyah," dalam MIQOT: Jurnal Ilmu-ilmu Keislaman, Vol. 36, No. 2, 2012; Ja'far, Ja'far, "Respons Dewan Fatwa Al Jam'iyatul Washliyah terhadap Isu Akidah dan Syariah di Era Global," dalam al-Manahij: Jurnal Kajian Hukum Islam, Vol. 10, No. 1, 2016; Ja'far, Ja'far, "Peran Al Jam'iyatul Washliyah dalam Merevitalisasi Madhhab Shafi'i di Era Kontemporer," dalam Justicia Islamica: Jurnal Kajian Hukum dan Sosial, Vol. 13, No. 1, 2016; Jafar, Jafar, "Al Jam'iyatul Washliyah dan Problem Kepemimpinan Non Muslim dan Perempuan," dalam AHKAM: Jurnal Ilmu Syariah, Vol. 17, No. 22017.
} 
Ketiga, di beberapa pendapatnya ada yang terkesan multi tafsir. Misalnya para pemuda dibolehkan memakai semir rambut semua warna dan orang yang sudah tua pun juga dibolehkan kecuali warna hitam. Namun pendapatnya yang lain, semua usia dibolehkan memakai semir rambut berbagai warna asalkan bukan warna hitam kecuali pada saat perang atau bagi perempuan yang ingin menyenangkan hati suaminya. ${ }^{6}$ Persoalan lainnya tentang memakai perhiasan emas bagi laki-laki. Menurut Asywadie Syukur hukum memakai perhiasan emas bagi laki-laki termasuk khilafiyah ${ }^{7}$ yang berpotensi boleh dipakai laki-laki.

Beberapa pendapat ini dan ditambah dengan pendapat-pendapat lainnya dipandang menarik dan penting untuk diteliti secara ilmiah. Penelitian ini diharapkan dapat mengungkapkan hal-hal yang berkaitan dengan pemikiran fikih Asywadie Syukur yang dimulai dari menguraikan pendapat-pendapatnya di bidang fikih, metode yang digunakan dan tipologi berpikir Asywadie Syukur.

\section{Sekilas tentang Asywadie Syukur}

Prof. Drs. H. Asywadie Syukur, Lc. lahir pada tanggal 8 Agustus 1939 dari pasangan Syukur dan Masliyah di Desa Benua Hulu Kecamatan Lahei Kabupaten Barito Utara Kalimantan Tengah. Kendati di usia dua tahun ditinggal wafat ibunya, tetapi ia dibesarkan dalam keluarga terdidik dan memiliki pengetahuan agama cukup luas. H. Maselah, saudara ayahnya, pernah menjadi kadi pertama di Muara Teweh. Ayah Asywadie Syukur walaupun pedagang tetapi aktif di tarekat Sadjaliyah. ${ }^{8}$ Ini menunjukkan Asywadie Syukur hidup di lingkungan keluarga religius dan kasih sayang sehingga ia tumbuh memiliki visi di masa mendatang. Selain itu ia juga dibesarkan di masyarakat plural tetapi bisa menghargai perbedaan bahkan dapat berdampingan secara harmonis.

Pendidikan Asywadie Syukur dimulai dari Sekolah Rakyat Negeri (SRN) di Benua Hulu Kecamatan Lahei. Setelah selesai tahun 1953 ia melanjutkan studi ke Sekolah Menengah Islam Pertama (SMIP) Hidayatullah Martapura Kabupaten Banjar Kalimantan Selatan. ${ }^{9}$ Jarak tempuh dari kampungnya ke SMIP Hidayatullah di Martapura sangat jauh tetapi tidak menyurutkan semangatnya. ${ }^{10}$ Tahun 1957 ia menyelesaikan pendidikan dan memperoleh dua ijazah yaitu ijazah dari SMIP dan dari SMPN. ${ }^{11}$ Tahun 1958 ia ditawarkan sekolah ke al-Azhar Mesir. Ia pun diterima dan mendapat beasiswa dari pemerintah Mesir. Awalnya

${ }^{6}$ Asywadie Syukur, Konsultasi Masalah Hidup dan Kehidupan, ed. Nasrullah, et al. (Banjarmasin: Pusat Pengkajian Islam Kalimantan IAIN Antasari Banjarmasin, 2002), Jilid I, h. 7-11.

${ }^{7}$ Ibid., h. 11-16.

${ }^{8}$ Nahed Nuwairah, "Hak dan Kewajiban Warga Negara Menurut Asywadie Syukur" (Tesis, IAIN Antasari Banjarmasin, 2007), h. 25.

${ }^{9}$ Taslim, "Hukum Bunga Bank Menurut K.H. M. Asywadie Syukur dan K.H. Husin Naparin (Studi Komparasi Pemikiran Hukum Islam)" (Tesis: IAIN Antasari Banjarmasin, 2006), h. 42. ${ }^{10}$ Ibid., h. 43.

${ }^{11}$ Ibid. Lihat juga Dahlan, et al., H.M. Asywadie Syukur, h. 23. 
diterima di kelas dua Ma'had Buhûts al-Islâmiyah al-Azhar; sebuah sekolah khusus yang disediakan untuk sisa yang datang dari luar Mesir setingkat dengan madrasah Aliyah. Tahun 1960 ia diterima di Fakultas Syari'ah Universitas al-Azhar. Tahun 1965 dapat menyelesaikan studinya dengan gelar Lc dan pulang ke Indonesia. Bertepatan tahun wafat ayahnya, di tahun 1967 ia menjadi Dosen Fakultas Syari'ah IAIN Antasari Banjarmasin. ${ }^{12}$ Tahun 1971 ia mengikuti Post Graduate Course di IAIN Sunan Kalijaga selama tiga bulan mempelajari fikih dengan Prof. T.M. Hasbi ash-Shiddieqy, kuliah sejarah dengan Prof. Mukhtar Yahya dan hukum pidana dengan Mulyono. ${ }^{13}$

Tahun 1975 Asywadie Syukur kembali ke Mesir kuliah Strata Dua Ushul Fikih di al-Azhar. Namun setelah mencapai dua tahun pemerintah Mesir mengeluarkan peraturan Strata Dua mesti ditempuh selama tiga tahun, akhirnya gelar tersebut tidak sempat diraihnya. Ia pun pulang ke Indonesia tahun 1976 dan langsung mengajar serta ditempatkan di Fakultas Dakwah IAIN Antasari Banjarmasin. ${ }^{14}$ Di samping mengajar, ia juga kuliah di Jurusan Qadha Fakultas Syari'ah IAIN Antasari Banjarmasin dan tahun 1980 meraih gelar Doktorandus. ${ }^{15}$ Di samping berdisiplin ilmu fikih dan ushul fikih, ia mempelajari ilmu Tasawuf, terlebih lagi sejak lama bergabung dalam Tarekat Naqsyabandiyah Khalidiyah. ${ }^{16}$

Berkaitan dengan karir, tahun 1968-1970, Asywadie Syukur menjadi Pembantu Dekan III Fakultas Tarbiyah IAIN Antasari Banjarmasin. Periode 1970-1975, ia menjadi Dekan Fakultas Dakwah. Pada 1981-1983 terpilih kembali di jabatan yang sama, tetapi tahun ini adalah masa singkatnya menjadi dekan, karena di periode 1982-1987 ia menjadi anggota Dewan Perwakilan Rakyat (DPR) Tingkat I Kalimantan Selatan. Setelah masa jabatannya berakhir, ia kembali ke kampus dan periode 1995-1998 menjadi Dekan di Fakultas yang sama. Ditambah dengan karir di bidang lain dan belum berakhir masa jabatannya sebagai Dekan ia kemudian terpilih menjadi Rektor IAIN Antasari periode 1997-2001. ${ }^{17}$ Pada periode ini pula (1997-2002) ia juga terpilih menjadi anggota MPR RI Utusan Daerah Kalimantan Selatan. Seiring dengan terbitnya peraturan tentang larangan bagi Pegawai Negeri Sipil untuk terlibat dalam politik, sejak tahun 2002 ia tidak lagi melibatkan diri di politik. ${ }^{18}$

Semasa Asywadi Syukur menjadi Rektor, Pascasarjana IAIN Antasari Banjarmasin berhasil dibuka. Banyak hal yang dilakukannya termasuk mempelopori pertemuan Rektor IAIN dan UIN se-Indonesia yang diawali di IAIN Antasari Banjarmasin sendiri di tahun 2000. ${ }^{19}$

\footnotetext{
${ }^{12}$ Nuwairah, "Hak dan Kewajiban", h. 23.

${ }^{13}$ Ibid., h. 24. Dahlan, et al., H.M. Asywadie Syukur, h. 25.

${ }^{14}$ Taslim, "Hukum Bunga", h. 43-44. Nuwairah, "Hak dan Kewajiban", h. 23.

${ }^{15}$ Taslim, "Hukum Bunga", h. 44.

${ }^{16}$ Nuwairah, "Hak dan Kewajiban", h. 25.

${ }^{17}$ Ibid., h. 29 dan 37.

${ }^{18}$ Dahlan, et al., H.M. Asywadie Syukur, h. 30-31, 37.

${ }^{19}$ Ibid., h. 33.
} 
Asywadie Syukur aktif di bidang dakwah dan dalam berbagai organisasi baik politik, kemasyarakatan atau keagamaan. ${ }^{20}$ Di bidang dakwah yang membuatnya dikenal luas ketika ia mengasuh acara "Konsultasi Masalah Hidup dan Kehidupan" di RRI Nusantara III Banjarmasin sejak tahun 1971 sampai 1994. ${ }^{21}$ Acara ini diterima masyarakat Muslim di berbagai daerah baik di Kalimantan Selatan, Kalimantan Tengah, Kalimantan Timur, Kalimantan Barat, Nusa Tenggara Barat, Nusa Tenggara Timur, Jawa Timur, Jawa Tengah, Madura dan bahkan Malaysia. ${ }^{22}$ Persoalan-persoalan yang dikonsultasikan cukup beragam melingkupi persoalan keagamaan dan kemasyarakatan.

Adapun kesibukannya di organisasi keagamaan, Asywadie Syukur hanya aktif di Majelis Ulama Indonesia (MUI). Pada periode 1980-1985, 1985-1995 dan 1990-1995 ia dipercaya berturut-turut sebagai Ketua Komisi Fatwa MUI Propinsi Kalimantan Selatan. Namun belum berakhir masa jabatannya periode 1990-1995, tahun 1992 Ketua Umum MUI Provinsi Kalimantan Selatan H. Zaini Mansyur ${ }^{23}$ wafat sehingga kepemimpinan Ketua Umum diserahkan kepada Asywadie Syukur sampai akhir periode tahun $1995 .{ }^{24}$ Periode 1995-2000, 2001-2005 dan 2006-2011, ia dipercaya menjadi Ketua Umum MUI Kalimantan Selatan. ${ }^{25}$ Belum habis masa jabatan periode ketiga, Sabtu petang di RSUD Ulin Banjarmasin tanggal 27 Maret 2010 Asywadie Syukur dipanggil Allah untuk menghadap kehadirat-Nya.

Karya tulis Asywadie Syukur sebenarnya cukup banyak baik berupa buku, terjemahan, makalah ataupun tulisan-tulisanya di berbagai media cetak. Karya dalam bentuk buku ada sekitar 31 judul dan dalam bentuk terjemahan sekitar 17 buah. Namun karena sebagian tulisannya ada yang tidak terarsipkan sehingga beberapa karya dan pemikirannya ada yang tidak ditemukan lagi. Di antara karyanya yang populer adalah Ilmu Tasawuf, Jilid 1 dan 2 diterbitkan tahun 1978. Tahun 1980 terbit lagi Perbandingan Mazhab. Tahun 1982 terbit Bimbingan Ibadah Bulan Ramadhan. Tahun 1985 terbit Intisari Hukum Perkawinan dalam Fikih Islam. Tahun 1990 terbit Pengantar Ilmu Fikih dan Ushul Fikih. Semua buku di atas diterbitkan Bina Ilmu Surabaya. Karya-karya lainnya diterbitkan di lingkungan kampus atau di Kalimantan Selatan, termasuk hasil tanya jawab di RRI Banjarmasin jilid 1 diterbitkan PPIK IAIN Antasari tahun 2002 berjudul Konsultasi Hidup dan Kehidupan. Tahun 2010 diterbitkan kembali jilid 2 dan 3 dengan judul yang sama yang diterbitkan oleh Center For Community Development Studies Kalimantan.

Karya-karya terjemahan cukup banyak di antaranya kitab Sabilal Muhtadin sebanyak 2 jilid; terbitan terakhir tahun 2013 Bina Ilmu Surabaya. Terjemahan lainnya diterbitkan Bina Ilmu tahun 2005 berjudul al-Milal wa al-Nihal: Aliran-Aliran Teologi dalam Sejarah

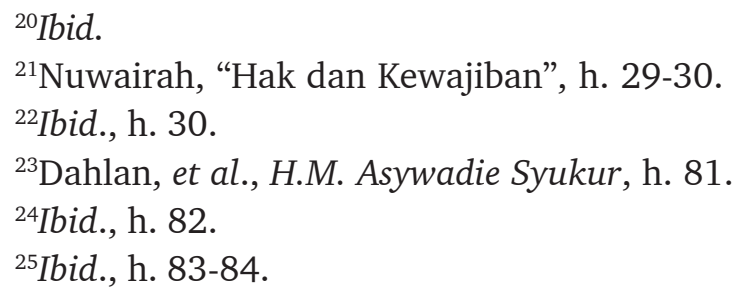


Umat Manusia. Asywadie Syukur juga aktif menulis di berbagai media cetak. Ia juga memiliki karya tulis berupa artikel, makalah, diktat, hasil penelitian yang tidak terpublikasikan. Di antaranya ada yang disampaikan pada forum nasional dan ada pula di forum internasional. Dengan karya-karya ini dapat menunjukkan Asywadie Syukur tidak hanya dikenal sebagai ulama tetapi dikenal pula sebagai akademisi dan penulis produktif.

\section{Beberapa Pendapat Muhammad Asywadie Syukur}

Pendapat-pendapat Asyawdie Syukur dapat diklasifikasi kepada ibadah dan muamalah. Namun dalam tulisan ini hanya diambil beberapa persoalan yang terkait dengan muamalah yaitu tentang harta perpantangan dan ishlâh, cadar bagi perempuan, bunga bank, semir rambut bagi laki-laki dan perempuan, dan memakai emas bagi laki-laki.

\section{Harta Perpantangan dan Ishlâh}

Harta perpantangan dan ishlâh dipopulerkan Syekh Muhammad Arsyad al-Banjarî dalam Kitâb al-Farâ’idh. Asywadie Syukur mengkaji kembali persoalan ini karena menurutnya tampak relevan dengan kondisi masyarakat Banjar bahwa harta perpantangan dan ishlâh bukan persoalan baru lagi, melainkan telah mengakar dan hidup berabad-abad lamanya terutama di setiap pembagian harta waris. ${ }^{26}$

Menurut Asywadie Syukur, lahirnya ide harta perpantangan ini karena Syekh al-Banjarî melihat adanya perbedaan masyarakat Arab dan Banjar. Perempuan di kalangan Arab tidak ikut bekerja menafkahi keluarga sehingga ketika suami meninggal dunia, istri mendapatkan bagian waris seperti yang ditentukan dalam Q.S. al-Nisâ/4: 11-12. ${ }^{27}$ Kendatipun istri ikut bekerja tetapi dipandang sebagai bantuan pada suami dan tidak menjadikannya sebagai pemilik harta. Sebaliknya seluruh harta yang ada di rumah tangga ada dalam otoritas suami. Istri hanya memiliki tugas berada di rumah. ${ }^{28}$

Berbeda dengan masyarakat Banjar, istri ikut bekerja untuk mencukupi kebutuhan ekonomi keluarga sehingga sebelum pembagian dilakukan, perlu adanya pemenuhan hakhak terkait keikutsertaan istri ini. Jika salah seorang dari suami istri meninggal dunia, terlebih dahulu dilakukan penghitungan seluruh harta yang diperoleh sejak akad nikah. Setelah itu pasangan yang masih hidup mendapatkan 50\% dari keseluruhan harta dan 50\% sisanya dibagi sesuai dengan ketentuan hukum farẩidh termasuk pasangan yang masih hidup pun

${ }^{26}$ Asywadi Syukur, "Konsep Harta Perpantangan dan Ishlah Menurut Syekh Muhammad Arsyad al-Banjari” (kumpulan makalah VI, tidak diterbitkan), h. 59.

${ }^{27}$ Ibid., h. 60.

${ }^{28}$ Muhammad Nasir, "Resistensi Ulama Dayah Aceh Tamiang terhadap Hak-Hak Perempuan dalam KHI," dalam MIQOT: Jurnal Ilmu-ilmu Keislaman, Vol. 41, No. 1, 2017, h. 46. 
masih mendapatkan harta waris sesuai dengan bagiannya. ${ }^{29}$ Hubungan baik antar keluarga pun dapat terjaga karena konsep harta perpantangan ini adalah memperkecil ruang perselisihan. ${ }^{30}$ Istilah harta perpantangan ini belakangan dikenal dengan sebutan harta bersama atau ada juga yang menyebutnya harta "bagi paro." 31

Adapun ishlâh adalah kemufakatan dalam pembagian harta waris. Para ahli waris terlebih dahulu melakukan penghitungan melalui farâidh dan baru kemudian mengadakan ishlâh. Bentuk ishlâh ini adalah para ahli waris bersepakat untuk menyerahkan sebagian harta waris yang diterimanya kepada ahli waris lainnya yang mendapatkan bagian lebih kecil. Tambahan bagian ini menurut Syekh al-Banjarî bukan sebagai harta warisan melainkan pemberian ahli waris yang lain, sehingga pemberian ini pun bersifat suka rela dan bukan paksaan. ${ }^{32}$

Dua pemikiran di atas ternyata diserap Kompilasi Hukum Islam (KHI). ${ }^{33} \mathrm{Hal} \mathrm{ini} \mathrm{menunjukkan}$ adanya kebijakan hukum ${ }^{34}$ yang patut diperjuangkan karena memiliki nilai kemaslahatan yang besar. Harta perpantangan dirumuskan menjadi harta bersama yang tertuang pada pasal 96 ayat (1) Instruksi Presiden Nomor 1 Tahun 1991 tentang KHI "Apabila terjadi cerai mati, maka separo harta bersama menjadi hak pasangan yang hidup lebih lama". Ishlâh dituang ke dalam pasal $183 \mathrm{KHI}$ "para ahli waris dapat bersepakat melakukan perdamaian dalam pembagian harta warisan setelah masing-masing menyadari bagiannya".

Menurut Asywadie Syukur, harta perpantangan dan ishlâh yang awalnya sebagai fikih lokal, kemudian diterima masyarakat luas dan diterapkan secara nasional sebagai aturan patut dipraktikkan masyarakat Islam Indonesia. Sebab lanjutnya aturan ini sangat relevan dengan situasi dan kondisi masyarakat Islam Indonesia, bahkan ia juga berharap peraturan kewarisan itu dapat dirumuskan menjadi undang-undang; tidak hanya sebagai Instruksi Presiden. ${ }^{35}$

\section{Bunga Bank}

Menurut Asywadie Syukur, ada dua pendapat terkait hukum bunga bank. Ada yang mengatakan sebagai riba nasîa h sehingga hukumnya haram, ${ }^{36}$ dan ada juga yang mengatakan

${ }^{29}$ Ibid., h. 60.

${ }^{30}$ Ahmad Dakhoir, "Pemikiran Fiqih Shaikh Muhammad Arshad al-Banjari," dalam Islamica, Vol. 4, No. 2, 2010, h. 230.

${ }^{31}$ Layyin Mahfiana, "Konsepsi Kepemilikan dan Pemanfaatan Hak atas Tanah Harta Bersama antara Suami dan Istri," dalam Bauana Gender, Vol. 1, No. 1, 2016, h. 33.

${ }^{32}$ Syukur, "Konsep Harta Perpantangan", h. 60-61.

${ }^{33} I$ Ibid., h. 61.

${ }^{34}$ Elfia, "Ishlah dalam Takharuj Menurut Hanafiyah Versus Ishlah dalam Kompilasi Hukum Islam (Analisis Kebijakan Hukum)," dalam Jurnal Ilmu Syari'ah, Vol. 17, No. 1, 2018, h. 21. ${ }^{35}$ Syukur, "Konsep Harta Perpantangan", h. 61.

${ }^{36} \mathrm{Di}$ Indonesia ada beberapa organisasi keagamaan, bahkan MUI pun juga mengharamkan 
bukan riba sehingga hukumnya mubah. ${ }^{37}$ Kelompok yang mengatakan sebagai riba nasî’ah disamping berdalil Q.S. Ali Imrân/3: 130 “........” juga memaknai Q.S. al-Baqarah/2: 278 “........ yaitu “...tinggalkan semua (macam) riba...”. Padahal jika melihat terjemahan Departemen Agama RI ayat ini diartikan “...tinggalkan sisa riba (yang belum dipungut)...”. Makna yang kedua menurut Asywadie Syukur lebih tepat karena ia tidak mencakup bunga bank konvensional. ${ }^{38}$

Kelompok yang mengharamkan juga berdalil hadis Nabi “"كل قرض جرّ منفعة فهو رب؟, tetapi hadis ini dinyatakan dha ‘îf. ${ }^{39}$ Upaya lainnya mereka mengqiyâskan bunga bank menjadi far'u dan bunga riba nasî'ah sebagai ashl. Qiyâs ini dipandang tidak tepat karena kedua transaksi di atas jauh berbeda sehingga disebut qiyâs ma'a al-fâriq. ${ }^{40}$ Dalam ushul fikih qiyâs ma'a al-fâriq terjadi karena adanya perbedaan 'illah. Asywadie Syukur tampaknya melihat riba nasî’ah diharamkan karena illahnya berbentuk bunga berbunga pada kebutuhan konsumtif sehingga yang menjadi korban adalah masyarakat kecil, sementara bunga bank diberlakukan pada peminjam produktif dan memenuhi persyaratan. Beralasan inilah bunga bank tidak termasuk riba.

Kelompok yang menyatakan bunga bank bukan riba berpegang pada pendapat Muhammad Abduh yang menyatakan bunga bank adalah persoalan baru. Status hukumnya pun mesti melalui ijtihad sesuai dengan kondisi zaman. Asywadie Syukur sendiri berada di pihak yang menyatakan bunga bank bukan sebagai riba. Pendapat ini muncul karena pada kenyataannya bank konvensional berperan banyak dalam meningkatkan pembangunan dan ikut memperkuat perekonomian masyarakat. ${ }^{41}$ Namun di akhir pendapatnya, Asywadie Syukur menyatakan pentingnya kehadiran bank konvensional ini disamping perannya yang besar juga kondisi perekonomian masyarakat banyak tergantung dengan bank, sementara bank syariah belum bisa diandalkan untuk memperkuat ekonomi masyarakat. ${ }^{42}$ Pendapat Asywadie Syukur ini mesti dipahami sebagai pendapat kondisional. Jika dibandingkan dengan zaman sekarang, bank-bank Syariah telah bermunculan. Kendatipun banyak yang menilai eksistensi bank-bank Syariah juga tidak bisa lepas dari riba, tetapi setidaknya telah berupaya untuk mendekati ketentuan yang telah diajarkan dalam Islam.

bunga bank. Lihat Rudy Haryanto, "Bagi Hasil dan Bank Syari'ah (Solusi terhadap Bunga Bank)," dalam Al-Ihkam, Vol. 5, No. 2, 2010, h. 244.

${ }^{37}$ Asywadi Syukur, "Riba dan Bunga Bank" (kumpulan makalah VII, tidak diteribtikan), h. 16.

${ }^{38}$ Ibid., h. 17.

${ }^{39}$ Muhammad ibn Ismâ̂îl al-Amîr al-Shan'ânî, Subul al-Salâm al-Maushilah ilâ Bulûgh alMarâm, Jilid V (Riyâdh: Dâr ibn al-Jauzî, 1421), h. 133. Syekh Albânî sendiri juga menyatakan isnâduhu sâqith, dha'îf dan matrûk pada hadis di atas. Lihat ta'lîq Syaikh Albânî pada kitab Subul al-Salâm Syarh Bulûgh al-Marâm, Jilid III (Riyâdh: Maktabah al-Ma'ârf, 2006), h. 126-127.

${ }^{40}$ Syukur, "Riba dan Bunga", h. 17.

${ }^{41}$ Ibid., h. 18-19.

${ }^{42}$ Ibid., h. 20. 


\section{Semir Rambut bagi Laki-laki dan Perempuan}

Asywadie Syukur menyatakan Q.S. al-A'râf/7: 31, membolehkan berpenampilan menarik, rapi, bersih dan menggunakan perhiasan yang baik asalkan tidak berlebihan. ${ }^{43}$ Menyemir rambut merupakan bagian memperindah dan menghiasi diri, bahkan Rasulullah menganjurkan bersemir agar terlihat berbeda dengan Yahudi dan Nasrani yang melarang menyemir rambut. ${ }^{44}$ Namun karena hanya sebagai anjuran biasa para sahabat pun ada yang melakukannya seperti Abû Bakr dan 'Umar ibn Khaththâb, ada pula yang tidak melakukannya seperti 'Alî ibn Abî Thâlib, Anas ibn Mâlik dan lainnya. ${ }^{45}$

Kendati pun dibolehkan, para ulama rupanya menentukan warna-warna yang dapat digunakan. Orang-orang yang sudah tua bangka dan seluruh rambutnya berwarna putih dibolehkan memakai rambut berbagai warna asalkan bukan warna hitam. Alasannya karena semir warna hitam menyerupai rambut para pemuda sehingga tidak pantas bagi orang yang sudah tua bersemir warna hitam. ${ }^{46}$ Bagi yang belum mencapai usia tua bangka, di antara ulama ada yang hanya membolehkan dengan semir hitam, ada pula yang tidak membolehkan sama sekali, kecuali bagi perempuan yang ingin menyenangkan suami atau dalam keadaan perang untuk menakuti musuh. ${ }^{47}$

Asywadie Syukur sepertinya hanya menyimpulkan dari dua pemikiran di atas. Pertama, semua usia boleh memakai semir rambut berbagai warna kecuali bagi yang sudah tua, ia tidak boleh memakai semir warna hitam. Kedua, semua usia boleh memakai semir rambut berbagai warna asalkan bukan warna hitam kecuali pada saat perang bagi laki-laki yang sudah tua atau bagi perempuan yang ingin menyenangkan hati suaminya. ${ }^{48}$

Majelis Ulama Indonesia menetapkan boleh memakai semir rambut dengan beberapa syarat. ${ }^{49}$ Namun syarat yang ditentukan terlihat normatif bahkan sebagiannya ada yang terlihat longgar, seperti hanya menghindari warna hitam dan tidak menentukan batas usia pemakai sebagaimana yang dikemukakan para ulama di atas. ${ }^{50}$

\footnotetext{
${ }^{43}$ Asywadi Syukur, Konsultasi Masalah Hidup dan Kehidupan, Jilid I (Banjarmasin: Pusat Pengkajian Islam Kalimantan, 2002), h. 8.

${ }^{44}$ Al-Bukhârî, Shahîh al-Bukhârî, Jilid III, h. 1275.

${ }^{45}$ Syukur, Konsultasi Masalah Hidup, Jilid I, h. 9.

${ }^{46}$ Ibid.

${ }^{47}$ Ibid., h. 10.

${ }^{48}$ Ibid., h. 11.

${ }^{49}$ Lihat Fatwa Majelis Ulama Indonesia Nomor 23 Tahun 2012 tentang Menyemir Rambut.

${ }^{50}$ Di Brunai Darussalam yang berpegang secara kuat pada mazhab Syâfi'i sepertinya juga tidak menentukan batasan usia kebolehan mewarnai rambut asalkan bukan warna hitam, walaupun di sebagian bahasannya menyebutkan mewarnai rambut yang sudah memutih. Lihat Abdul Qayyum Aminuddin dan Mohd Anuar Ramli, "Penggunaan Mazhab selain Syafi'i dalam Fatwa Negara Brunei Darussalam," dalam Jounal of Fatwa Management and Research, Vol. 7, No. 1, 2016, h. 49.
} 
Terlepas dari berbagai hal di atas jika dikaitkan dengan kondisi sekarang tampaknya kebolehan memakai semir rambut sudah tidak relevan lagi. Anak-anak muda yang bersemir rambut berbagai warna cenderung dinilai negatif, terlebih jika dilakukan orang yang sudah tua tentu dinilai lebih negatif. Dilihat dari maqâshid al-syarî‘ah rambut yang disemir berwarna pada masa Rasulullah, mungkin bukan sebagai gaya atau adanya tendensi tertentu. Berbeda dengan sekarang khususnya di Indonesia ia menjadi simbol yang dalam dunia interaksi sosial cenderung dikonotasikan miring. Artinya, ada perbedaan gaya bergaul dan berpikir pada zaman sekarang dengan zaman dahulu. Hal ini tidak dapat dipungkiri karena hukum pun dapat berubah sesuai dengan perubahan zaman, tempat, kondisi dan budaya. Pernyataan ini sesuai dengan salah satu kaidah fikih 51.5نيّر الفتوى واختلافها بحسب تغيّر الازمنة, الامكنة, الاحرال, النّياتوالعوائس

Disamping itu pada awalnya bersemir adalah mubah tetapi ketika berdampak pada 52. مأدّى إلى الحرام فهو حرام keburukan (haram), ia pun akhirnya dilarang sebagaimana kaidah Dampak tersebut menjadi dalil dilarangnya sesuatu yang asalnya dibolehkan, sesuai kaidah 晶. Dengan demikian dapat disimpulkan bahwa zaman sekarang memakai semir rambut apapun warnanya tampaknya lebih cenderung membawa kepada ketidakbaikan sehingga hukumnya pun lebih dominan kepada haram.

\section{Cadar Bagi Perempuan}

Menurut Asywadie Syukur umat Islam di dunia ini terdiri dari berbagai suku dengan berbagai adat istiadat. Ada adat yang berasal dari Islam dan ada pula yang sebaliknya. Misalnya pakaian bagi seorang Muslimah yang dipakai suku tertentu di daerah tertentu, ada yang berasal dari suku yang lain. Di Timur Tengah penduduk yang tinggal di desa, lanjut Asywadie Syukur baik yang beragama Islam, Nasrani atau Yahudi memakai cadar (niqâb), sementara cadar adalah pakaian adat setempat dan bukan sebagai pakaian Muslimah. ${ }^{54}$

Pendapat di atas ternyata juga diakui beberapa Syekh al-Azhar bahwa wajah perempuan bukan termasuk aurat sehingga ketika wajah ini ditutup ia pun bukan termasuk ibadah. ${ }^{55}$ Dalam mazhab Syâfiî̀ walaupun terjadi perbedaan pendapat, tetapi terdapat qaul yang

${ }^{51}$ Ibn al-Qayyim al-Jauziyah, I'lâm al-Muwaqqiînn an Rabb al-Âlamîn, Jilid I (Riyâdh: Dâr Ibn al-Jauzî, 1423 H), h. 41.

52‘Izz al-Dîn ibn 'Abd al-Salâm, Qawâ'id al-Ahkâm fî Mashâlih al-Anâm, Jilid II (BeirutLebanon: Dâr al-Kutub al-'Ilmiyah, 1999), h. 141.

53Jalâl al-Dîn al-Suyûthî, al-Asybâh wa al-Nazhẩir (Beirut- Lebanon: Dâr al-Kutub al'Ilmiyah, 1983), h. 60.

${ }^{54}$ Asywadi Syukur, "Kesetaraan Pria dan Wanita Menurut Pandangan Islam" (kumpulan makalah IV, tidak diterbitkan), h. 112.

${ }^{55}$ Muhammad Sayyid Thanthawî, "Wajh al-Mar'ah laisa bi 'Aurah al-Niqâb 'Âdah lâ 'Ibâdah" dalam Mahmûd Hamdî Zaqzûq, al-Niqâb 'Âdah wa laisa 'Ibâdah (Kairo: Dâr al-Kutub al-Mishriyah, 2008), h. 13-14. 
menyatakan aurat perempuan adalah seluruh tubuh kecuali wajah dan telapak tangan. ${ }^{56}$ Menurut Abû Hanîfah di samping wajah dan telapak tangan, yang dikecualikan juga adalah kaki karena kaki merupakan anggota tubuh yang penting dalam bergerak dan berinteraksi baik terkait urusan dunia atau pun akhirat. ${ }^{57}$ Oleh karena itu, cadar memang budaya dari beberapa kalangan masyarakat, bahkan dalam mazhab Mâlikî makruh menggunakan cadar jika belum (bukan) menjadi budaya. ${ }^{58}$

Satu hal yang harus diakui cadar adalah persoalan khilafiyah. Disamping ada yang menyatakan sebagai budaya, ada juga yang menyatakan status hukumnya sebagai sunnah bahkan wajib.59 Oleh karena itu suatu kekeliruan jika cadar dijadikan tolak ukur kualitas keberagamaan seseorang, ${ }^{60}$ terlebih lagi untuk menyatakan kadar iman seseorang. Kekeliruan lainnya-jika cadar dipaksakan diterapkan dengan mengatasnamakan agama. Pemaksaan ini menurut Asywadie Syukur telah terjadi di Afghanistan khususnya di masa rejim Taliban. Pada masa ini mereka mewajibkan kaum perempuan memakai burghah (sejenisjilbâb yang menutup seluruh tubuh termasuk muka). Padahal, Islam hanya mewajibkan perempuan Muslimah memakai jilbâb (pakaian luar yang menutup seluruh tubuh kecuali muka) atau khimâr (kerudung) dan tidak mewajibkan memakai cadar. Oleh karena itu, lanjut Asywadie Syukur, baik cadar ataupun burghah bukan termasuk pakaian Muslimah yang diajarkan Islam. ${ }^{61}$

\section{Memakai Emas bagi Laki-Laki}

Asywadie Syukur menyatakan belum ditemukan satu ayat pun secara eksplisit menyebutkan hukum memakai emas bagi laki-laki, kecuali di beberapa hadis Nabi. Itu pun dipahami berbeda, ${ }^{62}$ ada yang memahami sebagai haram ${ }^{63}$ ada pula hanya makruh. ${ }^{64}$

${ }^{56}$ Ibrâhîm al-Baijûrî, Hâsyiyah al-Syaikh Ibrâhîm al-Baijûrî, Jilid II (t.t.: Dâr al-Fikr, t.t.), h. 100.

${ }^{57}$ Mahmûd Hamdî Zaqzûq, al-Niqâb 'Âdah wa laisa 'Tbâdah (Kairo: Dâr al-Kutub al-Mishriyah, 2008), h. 25.

58'Alî Jum'ah, "al-Niqâb Murthabath bi al-'Âdât," dalam Mahmûd Hamdî Zaqzûq, alNiqâb 'Âdah wa laisa 'Ibâdah (Kairo: Dâr al-Kutub al-Mishriyah, 2008), h. 15-16.

${ }^{59}$ Muhammad Kudhori, "Kontroversi Hukum Cadar dalam Perspektif Dialektika Syariat dan Adat," dalam Ijtihad Jurnal wacana Hukum dan Keislaman, Vol. 18, No. 1, 2018, h. 33.

${ }^{60}$ Ibid., h. 39.

${ }^{61}$ Syukur, "Kesetaraan Pria dan Wanita", h. 112.

${ }^{62}$ Syukur, Konsultasi Masalah Hidup, Jilid I, h. 13-15.

${ }^{63}$ Larangan minum di bejana emas lihat Abû 'Abdullâh Muhammad ibn Ismâ'îl al-Bukharî, Shahîh al-Bukhârî, Juz V (Beirut-Damaskus: Dâr Ibn Katsîr, t.th), h. 2070. Emas dan sutra hanya untuk perempuan lihat Abû 'Abdurrahmân Ahmad ibn Syu'aib al-Nasâ'î, Kitâb al-Sunan al-Kubrâ, Juz VIII (Beirut-Lebanon: Mu'assasah al-Risâlah, 2001), h. 358.

${ }^{64} \mathrm{Al}$-Barrâ' memakai cincin emas pemberian Rasulullah. Lihat Ahmad ibn Muhammad ibn Hanbal, al-Musnad li Imâm Ahmad ibn Muhammad ibn Hanbal, Hadis al-Barrâ ibn 'Azib, Nomor Hadis 17861 dalam Software Kitab 9 Imam Hadis. Hadis di atas ada dalam kitab hadis Albânî. Lihat Muhammad Nâshiruddîn al-Albânî, Silsilah al-Ahâdîts ash-Shahîhah, Jilid IV (Riyâdh: Makabah al-Ma'ârif, 2000), h. 345. 
Ulama empat mazhab sepakat mengharamkan laki-laki memakai emas karena dapat menimbulkan rasa angkuh pada si pemakai. Hal ini sesuai dengan kaidah fikih . Kendatipun ada pula beberapa hadis yang sepertinya membolehkan, tetapi hadis-hadis tersebut menurut mereka telah dinaskh oleh hadis-hadis yang melarang laki-laki memakai emas. ${ }^{66}$

Namun Ibn Hazm mengutip pendapat Qâdhî 'Iyâdh menyatakan makruh dan tidak sampai ke tingkat haram. Pendapat ini disamping didukung hadis yang mengandung pengertian makruh juga ada riwayat at-Thabrânî dari Jamîl ibn 'Abdullâh bahwa ia melihat lima sahabat Rasulullah memakai cincin emas, yaitu Zâid ibn Harîtsah, Zâid ibn Arqam, al-Barrâ', Ibn 'Âzîb dan 'Abdullâh ibn Zubair. ${ }^{67}$

Asywadie Syukur menilai hukum memakai emas bagi laki-laki termasuk khilafiyah. Bagi yang berpendapat makruh karena memandang hadis-hadis di atas tidak pernah dinaskh, sehingga walaupun dilarang tetapi larangan itu maksudnya hanya makruh. Asywadie Syukur menyatakan siapa pun dapat memilih salah satu yang terkuat dari kedua pendapat itu. ${ }^{68}$ Kendatipun demikian, tidak mungkin pula ada larangan di satu sisi secara bersamaan juga ada kebolehan di sisi lain. Hal ini mesti diselesaikan melalui ta'ârudh al-adillah versi Hanafiyah atau pun Syâfi'iyah. Versi Hanafiyah terhadap dalil yang bertentangan dilakukan terlebih dahulu naskh. Jika tidak diketahui mana yang lebih dahulu di antara keduanya maka dilakukan tarjîh untuk mencari yang terkuat dan jika sulit pula ditemukan maka dilakukan al-jam'wa al-taufiq yaitu mengkompromikan keduanya agar keduanya dapat diamalkan. Namun jika tidak bisa pula, berarti harus dilakukan tasâquth al-dalîlain yaitu tidak mengamalkan keduanya. Adapun versi Syâfi'iyah terlebih dahulu melakukan al-jam 'wa al-taufîq, baru tarjîh kemudian naskh dan terakhir tasâquth al-dalîlain. ${ }^{69} \mathrm{Jika}$ dilihat melalui teori ini, tampaknya hukum memakai emas bagi laki-laki lebih relevan menggunakan cara tarjîh walaupun Asywadie Syukur sendiri tidak menentukan pilihan.

\section{Metode Penetapan Hukum Muhammad Asywadie Syukur}

Dalam mengkaji suatu persoalan, Asywadie Syukur berupaya mengawali kajiannya dari ayat-ayat al-Qur'an. Hal ini terlihat ketika ia mengkaji hukum bunga bank dan menyemir rambut bagi laki-laki dan perempuan. Di dalam kajiannya ia mengemukakan ayat-ayat yang relevan dengan permasalahan. Hadis Nabi juga digunakan tetapi ia selalu menempatkan

${ }^{65}$ Al-Salâm, Qawấid al-Ahkâm, Jilid II, h. 141.

${ }^{66}$ Syukur, Konsultasi Masalah Hidup, Jilid I, h. 14.

${ }^{67}$ Al-Thabrânî, al-Mu'jam al-Shaghîr lithabrânî, Jilid I (Beirut- Lebanon: Dâr al-Kutub al'Ilmiyah, 1983), h. 166. Syukur, Konsultasi Masalah Hidup, Jilid I, h. 15.

${ }^{68}$ Ibid., h. 16.

${ }^{69}$ Wahbah al-Zuhailî, Ushûl al-Fiqh al-Islâmî, Jilid II (Damaskus: Dâr al-Fikr, 2001)-, h. 1201-1212. 
Hadis Nabi sesuai pada posisinya yaitu setelah al-Qur'an. Kendatipun ada juga yang langsung dibahas melalui Hadis Nabi seperti memakai emas bagi laki-laki, tetapi sangat mungkin persoalan tersebut tidak disebutkan secara langsung dalam al-Qur'an.

Asywadie Syukur tampaknya memperhatikan tartîb al-adillah ${ }^{70}$ yaitu memposisikan hadis sebagai sumber hukum kedua. Kedudukan seperti ini karena hadis berfungsi sebagai penjelas globalnya suatu ayat, pembatas mutlaknya suatu ayat, pengkhusus umumnya suatu ayat, bahkan sebagai penentu suatu hukum yang tidak ditemukan aturannya dalam al-Qur'an. Kendatipun teori tartîb al-adillah adalah hasil ijtihad ulama tetapi dengan adanya teori ini menjadikan hukum yang dibangun memiliki landasan yang kuat sehingga dipandang penting memperhatikan tartîb al-adillah dalam setiap berpendapat.

Setelah mengkaji suatu persoalan dari al-Qur'an dan Hadis, selanjutnya Asywadie Syukur menggunakan metode qaulî yaitu berpedoman dan mengemukakan pendapat ulama terdahulu, ${ }^{71}$ kecuali pada persoalan yang diyakini belum dibahas sebelumnya. Penggunaan pendapat ulama ini seharusnya dilakukan ulama di setiap generasi. Ini menunjukkan bahwa suatu pendapat dipandang ilmiah karena memiliki referensi yang dapat dipertanggungjawabkan. Sir Isaac Newton mengatakan ia mampu melihat ke depan karena ia berdiri di atas "bahu raksasa". ${ }^{72}$ Istilah bahu raksasa ini tentu maknanya berpijak pada pendapat para ulama sebelumnya yang mengisyaratkan pentingnya seorang berguru (talaqqî) dan gurunya juga berguru pada guru sebelumnya sampai seterusnya kepada para imam mazhab. Mereka merupakan guru dan murid yang sampai kepada imam Hanafî. Ulama ini disamping hidup di masa tâbi tâbiî̂n, ia juga menemui ulama masa tâbi în dan belajar dengan mereka bahkan dengan sahabat. Sahabat dipastikan pernah belajar dengan sahabat yang lebih 'âlim dan mereka juga dipastikan belajar langsung dengan Nabi Muhammad. Nabi sendiri di dalam Q.S. al-Najm/53: 3-4, tidak keluar satu pun dari mulutnya kecuali wahyu Allah yang juga ada di dalamnya peran Malaikat Jibril as.

Alur di atas menunjukkan pentingnya ilmu memiliki sanad. Al-Qur'an dan hadis tidak dapat dipahami dengan baik jika belajar tanpa berguru. Alasannya karena melalui guru dapat diketahui sebab-sebab turunnya wahyu dan hadis Nabi. Begitu juga dengan berguru dapat diketahui situasi dan kondisi masyarakat ketika suatu ayat diturunkan atau suatu hadis disampaikan.

${ }^{70}$ Muhammad ibn Husain ibn Hasan al-Jîzânî, Ma'âlim Ushûl al-Fiqh inda Ahl as-Sunnah wa al-Jamâ’ah (Riyâdh: Dâr ibn Jauzî, 1996), h. 284-286.

${ }^{71}$ Konsep metode qaulî ini biasa digunakan kalangan NU. Lihat dalam Aziz Masyhuri, Masalah Keagamaan NU (Surabaya: PP RMI dan Dinamika Press, 1997), 364. Lihat pula Ahmad Zahro, Tradisi Intelektual NU: Lajnah Bahtsul Masa’il 1926-1999 (Yogyakarta: LKiS, 2004), h. 118. Begitu juga lihat Ahmad Arifi, "Dinamika Fikih Pola Mazhab: Kontekstualisasi Bermazhab dalam Fikih NU," dalam Jurnal Asy-Syir'ah, Vol. 43, No. 1, 2009, h. 189-190.

${ }^{72}$ George Ritzer dan Douglas J. Goodman, Teori Sosiologi Modern, terj. Alimandan (Jakarta: Prenada Media Group, 2004), A-12. 
Setelah menguraikan pendapat-pendapat ulama dengan metode qauli,${ }^{73}$ atau disebut juga bentuk bermazhab, ${ }^{74}$ Asywadie Syukur menggunakan beberapa metode. Ia menggunakan metode muqâranah yaitu membandingkan satu pendapat dengan pendapat yang lain. Di dalam buku perbandingan mazhab Asywadie Syukur menguraikan persoalan-persoalan ibadah dengan cara membandingkan pendapat-pendapat ulama. Misalnya hukum air sedikit tercampur dengan najis tetapi tidak merubah bau, warna dan rasanya. Di antara ulama ada yang mengatakan air tersebut tidak menjadi air najis. Namun ada juga yang mengatakan air yang sedikit bercampur dengan najis walaupun tidak sampai merubah bau, warna atau rasanya tetap termasuk air najis. Setelah membandingkan kedua pendapat ini Asywadie Syukur memilih pendapat pertama yaitu air tersebut tetap suci tetapi makruh digunakan jika jumlah airnya kurang dari dua qullah.

Disamping menggunakan metode muqâranah Asywadie Syukur juga menggunakan metode tarjîh. Metode ini digunakan untuk menentukan pendapat yang terkuat dari beberapa pendapat ulama yang berbeda. Gaya ini terlihat dalam sikap hukum yang dilakukan Asywadie Syukur ketika mengkaji dan kemudian memilih pendapat pertama tentang hukum air di atas. Persoalan lainnya yang dikaji Asywadie Syukur dengan menggunakan metode tarjîh adalah hukum bunga bank. Ia menyatakan pendapat ulama yang lebih kuat adalah bunga bank tidak termasuk riba.

Pada sisi yang lain ia tidak menentukan sikap tetapi memberikan beberapa pilihan jawaban. Hal ini ketika ia menjelaskan hukum memakai emas bagi laki-laki yang menurutnya termasuk khilafiyah. Terkait cara ini tampaknya Asywadie Syukur menggunakan-yang penulis sebut-metode takhyîr ${ }^{75}$ yaitu memberikan kebebasan kepada masyarakat untuk memilih salah satu dari beberapa alternatif pendapat yang berbeda. Kendatipun adanya kebebasan memilih tetapi bukan berarti yang dicari adalah yang lebih mudah melainkan harus ditentukan berdasarkan kajian. Oleh karena itu lebih tepat jika para pelaku yang berada pada posisi memilih (takhyîr) dari beberapa pilihan adalah bukan dari kalangan awam dan setidaknya memahami hukum Islam dan metodologinya serta keilmuan pendukung lainnya.

Disamping menggunakan metode qaulî dengan beberapa metode yang menyertainya seperti metode muqâranah, tarjîh, dan takhyîr, Asywadie Syukur juga menggunakan kaidah-

${ }^{73}$ Menelusuri berbagai pendapat ulama terdahulu juga termasuk sebagai ketersambungan ilmu, kompas dalam mengkaji hukum, termasuk untuk perbandingan dan bahkan sebagai objek analisis. Lihat Abdul Helim, Menelusuri Pemikiran Hukum Ulama Banjar Kontemporer (Malang: Intelegensi Media, 2018), h. 188.

${ }^{74}$ Ahmad Arifi, "Dinamika Pemikiran Fikih dalam NU (Analisis atas Nalar Fikih Pola Mazhab," dalam Ulumuna, Vol. 13, No. 1, 2009, h. 193.

${ }^{75}$ Kata takhyîr ini sejatinya bagian dari hukum taklîfi yaitu kebebasan untuk memilih yang diberikan langsung oleh syâri‘. Dalam artikel ini kata ini dipinjam untuk menunjukkan metode yang digunakan Asywadie Syukur. Terkait dengan makna takhyîr, lihat Kamal Fiqry Musa, "Islamic Jurisprudence and Human Rights: At-Takhyîri Approach in Marriage Law," dalam International Conference on Law and Justice: Advance Social science, Education and Humanities Research, Vol. 162, 2017, h. 38. 
kaidah ushûlî baik yang lughawiyah atau pun ma'nawiyah. Kaidah ushûlîlughawiyah berisi tentang metode ushul fikih yang digunakan untuk menganalisis bahasa al-Qur'an dan Hadis, sementara kaidah ushûlîma'nawiyah berisi metode yang dirumuskan berdasarkan pemahaman terhadap makna al-Qur'an dan Hadis. ${ }^{76}$

Asywadie Syukur yang selalu merujuk pada kajian al-Qur'an dan Hadis, dipastikan menggunakan kaidah ushûlî lughawiyah. Misalnya dalam memahami katafí Sabîlillâh pada Q.S. al-Taubah/9: 60. Di antara ulama ada yang memahaminya mengandung pengertian khâsh yaitu hanya bermakna jihad, ada juga memahaminya 'âmm yaitu semua perbuatan yang mengandung kebajikan. Asywadie Syukur memahaminya sebagai 'âmm dan termasuk pula bermakna jihad tetapi dalam makna jihad terhadap kemiskinan, kebodohan, keterbelakangan, dekadensi moral akibat era globalisasi dan arus informasi tanpa batas. ${ }^{77}$

Pada persoalan lainnya Asywadie Syukur juga menggunakan kaidah ushûlîmánawiyah. Salah satunya adalah metode qiyâs..$^{78}$ Metode ini digunakan ketika ia mengkaji pendapat ulama yang menyatakan bunga bank adalah riba sebagai hasil dari qiyâs bunga bank dengan riba nasîah. Asywadie Syukur juga menganalisis pendapat tersebut menggunakan metode qiyâs tetapi menyatakan kedua transaksi itu sebenarnya jauh berbeda. Perbedaan tersebut terlihat dari perbedaan 'illah (motif terbentuknya hukum). Masyarakat yang meminjam uang dalam bentuk riba nasîah karena terpaksa untuk kebutuhan hidup sehingga nilai guna dari pinjaman itu hanya bersifat konsumtif. Berbeda dengan meminjam uang di bank yang beralasan bukan karena terpaksa tetapi justru produktif untuk mengembangkan hidup atau pun usaha. Menurut Asywadie Syukur penyamaan hukum di atas termasuk qiyâs ma'a al-fâriq ${ }^{79}$ yaitu qiyâs yang tidak dapat diterima karena adanya perbedaan 'illah pada bunga bank dengan 'illah pada riba nasî’ah.

Metode lainnya yang digunakan Asywadie Syukur adalah istihsân. ${ }^{80}$ Dengan menggunakan metode ini ia menyatakan perempuan haid dibolehkan membaca dan menyentuh al-Qur'an ketika mengikuti ujian, sementara ujian ini mesti diikuti dan tidak dapat ditunda. Hal lainnya dibolehkan juga bagi perempuan meminum obat penunda haid agar dapat melaksanakan ibadah haji khususnya ketika tawaf ifâdhah.

Metode berikutnya yang tampaknya digunakan juga adalah 'urf. Dari metode ini ia sependapat dengan pemikiran Syekh Muhammad Arsyad al-Banjari tentang hukum harta

${ }^{76}$ Bandingkan dengan istilah lain seperti yang digunakan Muhammad Salâm Madkûr, alIjtihâd fî al-Tasyrî‘ al-Islâmî (t.t.: Dâr al-Nahdhah, 1984), h. 42-49.

${ }^{77}$ Asywadie Syukur, "Pengetian fi Sabilillah sebagai Salah Satu Asnaf Zakat" (kumpulan makalah II, tidak diterbitkan), h. 31.

${ }^{78}$ Lihat makna qiyâs dalam Saif al-Dîn Abî al-Hasan 'Alî ibn Abî 'Alî ibn Muhammad alAmidî, al-Ihkâm fî Ushûl al-Ahkâm, Jilid II, Juz. III (Beirut-Lebanon: Dâr al-Fikr, 1996), h. 130.

${ }^{79}$ Al-Zuhailî, Ushûl al-Fiqh, Jilid I, h. 644.

${ }^{80}$ Lihat makna istihsân dalam Husain Muhammad Mallâh, al-Fatwâ: Nasy'atuhâ wa Tathawwuruhâ-Ushûluhâ wa Tathbîqâtuhâ, Jilid II (Beirut: al-Maktabah al-'Ashriyah, 2001), h. 469. Lihat juga Al-Zuhailî, Ushûl al-Fiqh, Jilid II, h. 738. 
perpantangan dan ishlâh. Dilatarbelakangi perbedaan budaya Banjar dengan Arab menjadikan sebuah ketetapan hukum bisa berbeda, salah satunya tentang harta perpantangan. Dalam budaya Banjar istri ikut bekerja untuk menunjang perekonomian keluarga sehingga jika suami meninggal dunia, istri mendapatkan 50\% dari keseluruhan harta dan bagian 50\% lainnya disebut harta warisan yang dibagikan secara farâ'idh. Dalam harta warisan ini istri masih memiliki hak mendapat sebesar $1 / 8$ jika memiliki anak dan $1 / 4$ jika tidak punya anak. Artinya, disamping mendapatkan 50\% dari harta perpantangan, juga mendapat $1 / 8$ atau $1 / 4$ dari harta warisan. Ketentuan ini secara otomatis berlaku pada suami, ia mendapat 50\% dari harta keseluruhan dan dari 50\% sisanya mendapatkan sebesar 1/4 jika memiliki anak atau 1/2 jika tidak memiliki anak. Istilah harta perpantangan ini telah diterima dan menjadi salah satu aturan di Indonesia yang disebut dalam Kompilasi Hukum Islam sebagai harta bersama.

Adapun ishlâh juga merupakan hasil dialog budaya lokal dan ditambah dengan perbedaan masa dengan hukum waris Islam. Dalam kaidah fikih “ لاينكر تغيّر الأحكام بتغيّر الأزمنة والأمكنة bahwa tidak dapat dipungkiri berubahnya suatu hukum karena adanya perubahan (perbedaan) zaman dan tempat, maka dengan pertimbangan kaidah ini para ahli waris yang mengetahui bagian mereka masing-masing secara farâ'idh, dapat membuat kesepakatan untuk membantu ahli waris lainnya dengan cara mengurangi bagian yang diterimanya dan memberikan bagian tersebut ke ahli waris yang lain. Pemikiran ini relevan dengan kondisi masyarakat Islam Indonesia dan sejak tahun 1990 ishlâh diterima menjadi fikih Indonesia.

Persoalan berikutnya yang dikaji melalui 'urf terkait dengan cadar (niqâb). Asywadie Syukur menyatakan cadar adalah pakaian adat masyarakat di daerah Timur Tengah dan karena sebagai adat maka cadar digunakan perempuan yang beragama Islam, Nasrani atau Yahudi. Oleh karena itu menurut Asywadie Syukur cadar bukan ajaran Islam tetapi hanya sebagai budaya yang masuk ke dalam Islam.

Pada dasarnya sepanjang adat atau budaya ini mengandung kemaslahatan dan tidak bertentangan dengan syara' maka dalam 'urf disebut sebagai 'urf shahîh (budaya yang dapat diterima dalam Islam). Hal ini berlaku baik pada harta perpantangan dan ishlâh yang disebutkan di atas serta tidak terkecuali cadar. Berbeda misalnya cadar dipaksakan pada masyarakat yang sejak dahulu sudah terbiasa melihat wajah dan menyatakan salah atau istilah laisa minn $\hat{a}^{81}$ pada orang yang tidak bercadar, maka gaya berpikir seperti ini berpotensi menimbulkan perselisihan dan perpecahan di kalangan umat Islam. Berbahaya lagi jika gaya berpikir laisa minnâ menjadi budaya akan memicu timbulnya saling mengkafirkan yang akhirnya dapat dikategorikan sebagai 'urffâsid. Saling mengkafirkan merupakan

${ }^{81}$ Terkadang berpikir laisa minnâ ini menimbulkan gerakan ekstrim seperti penyebutan bidah dan takfiri (pengkafiran) pada orang lain yang berbeda dengannya. Moh. Dahlan, "Moderasi Hukum Islam dalam Pemikiran Ahmad Hasyim Muzadi," dalam al-Ihkam, Vol. 11, No. 2, 2016, h. 318. 
kemudaratan yang sangat berbahaya. Dalam metode mashlahah hal itu termasuk perbuatan yang dilarang karena jika dilihat dari maqâshid al-syarî‘ah ia dapat mengganggu kelima atau sebagian besar dari unsur-unsur pokok yang harus dijaga baik agama, jiwa, akal, keturunan atau pun harta.

Selanjutnya di bagian akhir ketika menuliskan suatu pendapat Asywadie Syukur tidak jarang menuliskan kaidah-kaidah fikih. Artinya disamping menggunakan metodemetode ushul fikih, ia juga menggunakan kaidah-kaidah fikih untuk mendukung kajian hukum yang dilakukannya. Fungsi utama dari kaidah-kaidah fikih ini adalah sebagai penghimpun dari beberapa hasil kajian (fikih) furû' yang sama tema. ${ }^{82}$ Misalnya ada sebuah persoalan, maka proses yang dilakukan terlebih dahulu mengkaji melalui ushul fikih. Hasil kajian ini disebut produk atau status hukum atau disebut juga fikih. Untuk menguatkan status hukum atau fikih ini, kemudian dikaji dan dicari kaidah-kaidah fikih yang relevan.

Contohnya Asywadie Syukur menyatakan boleh bagi perempuan haid membaca dan menyentuh al-Qur'an saat mengikuti ujian dan boleh juga menunda haid agar dapat melaksanakan 4" الضرورات تبيح الدحظورات" bahwa kondisi darurat itu membolehkan melakukan perbuatan yang awalnya dilarang.

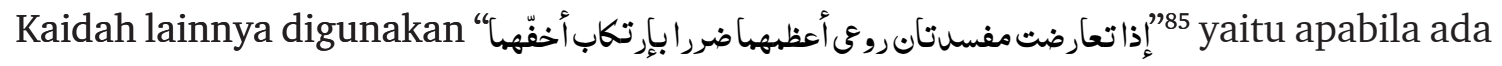
dua kemudaratan yang saling bertentangan, maka yang dicari adalah kemudaratan mana yang lebih besar dari keduanya dengan cara mengerjakan kemudaratan yang lebih ringan (kecil) dari keduanya.

Itulah beberapa metode hukum yang digunakan Asywadie Syukur dalam berpendapat. Kendatipun metode-metode tersebut tampaknya belum ada yang berbeda dari metodemetode yang diperkenalkan ulama terdahulu tetapi Asywadie Syukur telah menunjukkan upaya untuk menjelaskan hukum secara metodologis.

\section{Tipologi Pemikiran Fikih Muhammad Asywadie Syukur}

Prinsip hati-hati merupakan satu hal yang harus disepakati dalam menentukan kecenderungan mazhab fikih seseorang. Begitu juga dengan Asywadie Syukur, untuk membaca kecenderungan mazhab yang diikutinya tentu tidak dapat hanya melihat dari salah satu sisi, terlebih lagi di antara metode hukum yang sering digunakannya adalah

${ }^{82}$ Muhammad Shidqî ibn Ahmad al-Burnû, al-Wajîz fì Idhâh Qawâ'id al-Fiqh al-Kulliyah (Beirut-Lebanon: Mu'assasah al-Risâlah, 1982), h. 17-18.

${ }^{83}$ Sebagai contoh praktik penggunaan kaidah fikih yang dimaksud lihat Asywadie Syukur, "Hukum Wanita Haidh Membaca dan Menulis Ayat Al-Qur'an dalam Ujian" (kumpulan makalah II, tidak diterbitkan), h. 88.

${ }^{84}$ Lihat Al-Suyûthî, al-Asybâh wa al-Nazhâ'ir, h. 23.

${ }^{85}$ Shâlih ibn Ghânim al-Sadlân, al-Qawâ'id al-Fiqhiyah al-Kubrâ wamâ Tafarra 'anhâ (Riyâdh: Dâr Balansiah, 1417), h. 527. 
muqâranah dan tarjîh. Hasil kajian dari kedua metode tersebut tidak hanya bisa menguatkan mazhab tertentu tetapi bisa juga menguatkan mazhab yang lain. Namun bukan berarti Asywadie Syukur tidak bermazhab.

Kendatipun secara formal ia hanya memperlihatkan dirinya di Majelis Ulama Indonesia tetapi bisa jadi ia memiliki maksud-maksud lain. Terlebih perbedaan antar organisasi keagamaan di Indonesia terlihat begitu tajam sehingga ia merasa lebih tepat berada di posisi untuk menenangkan. Posisi yang lebih tepat pada waktu itu adalah Majelis Ulama Indonesia karena hanya di organisasi ini tempat berkumpulnya ulama-ulama berbagai organisasi. Disamping itu prinsip berdirinya Majelis Ulama Indonesia ini adalah dîniyah, irsyâdiyah, istijâbiyah, hûriyah, tasâmuh, qudwah, duwaliyah adalah prinsip kebersamaan dan kesatuan antar umat Islam dan terhadap umat beragama yang lain tampaknya membangkitkan semangat Asywadie Syukur untuk berkonsentrasi di Majelis Ulama Indonesia. Terlepas dari berbagai kemungkinan di atas, kemungkinan lainnya bisa jadi secara informal dan tanpa diketahui umum bahwa Asywadie Syukur mengikuti mazhab tertentu.

Namun untuk memastikan posisi yang lebih dominan, tentu harus berangkat dari data. Data yang dimaksud setidaknya berupa referensi-referensi yang digunakan Asywadie Syukur. Beberapa kitab yang sering dijadikannya sebagai rujukan seperti kitab Badâ'i‘ al-Shanâ'i‘ karya al-Kâsânî al-Hanafi, kitab Mawâhib al-Jalîl li Syarh Mukhtashar al-Khalîl karya al-Haththâb al-Ru'yanî al-Mâlikî, kitab al-Mughnî karya Ibn Qudâmah al-Hanbalî, kitab al-Majmû' Syarh al-Muhadzdzab li Syîrâzî karya Abû Zakariyâ al-Nawawî al-Syâfiî̀, kitab al-Azîz Syarh al-Wajîz karya al-Râfi'î al-Qazwînî al-Syâfi'î, kitab Nihâyat al-Muhtâj ilâ Syarh al-Minhâj karya al-Ramlî al-Syâfiî̀ dan termasuk pula kitab-kitab belakangan yang bermazhab Syâfi'î, bahkan kitab Ihyâ 'Ulûm al-Dîn karya al-Ghazâlî yang ada kaitannya dengan hukum Islam.

Jika hanya melihat dari intensitas penggunaan beberapa karya di atas, Asywadie Syukur lebih cenderung dan banyak menggunakan karya-karya ulama Syâfiî̀. Di antara karya yang paling sering dirujuk adalah kitab al-Majmû' Syarh al-Muhadzdzab li Syîrâzî karya Abû Zakariyâ al-Nawawî al-Syâfi'î. Berdasarkan kecenderungan ini tampaknya Asywadie Syukur dapat dikategorikan bermazhab Syâfiî̀.

Kendatipun berkecenderungan ke mazhab Syâfiî,, Asywadie Syukur pun dalam menyatakan pendapat disamping menentukan (tayîn) pendapat yang terkuat yang dihasilkan dari tarjîh, juga mempersilahkan kepada orang untuk memilih (takhyîr) di antara beberapa pendapat yang dianggap kuat. Cara seperti itu bukan berarti ia tidak bermazhab tetapi justru dapat dikategorikan sebagai orang yang tidak memaksakan pendapatnya atau pendapat yang diikutinya kepada orang lain..$^{86}$ Sebaliknya dari beberapa pendapat yang diuraikan, Asywadie

${ }^{86}$ Sepertinya tidak keliru 'Abdullâh ibn Mas'ûd berkata: "aqûlu hâdzâ bi ra'yî, fa in kâna hâdzâ shawâban fa minallâh, wa in yakun khatha'an fa minnî wa min asy-syaithân". Lihat Abû Zahrah, Al-Syafiî Hayâtuhû wa 'Ashrû Arâ'uhû wa Fiqhuhû (t.t.: Dâr al-Fikr al-'Arabî, 1978), 
Syukur memberikan kebebasan dari beberapa alternatif pendapat laksana menyajikan menu makanan untuk dipilih para pemesan. Penilaian tidak bermazhab terhadap Asywadie Syukur muncul sebagai akibat sikap hukum seperti ini tentu tidak dapat dihindarkan dan sikap hukum seperti itu terkadang dinilai sebagai salah satu bentuk kemerosotan, ${ }^{87}$ tetapi dengan kecenderungannya merujuk pada karya-karya ulama Syâfiî̀ dipandang telah cukup beralasan untuk menyatakan bahwa Asywadie Syukur bermazhab Syâfiî̀.

Selanjutnya berkaitan dengan kecenderungan pola pikir tampaknya Asywadie Syukur berada pada tipologi neo-tradisionalisme bermazhab ${ }^{88}$ yaitu berpegang pada beberapa mazhab fikih. Disebut demikian karena Asywadie Syukur selalu merujuk pada pendapatpendapat ulama mazhab. Namun sebagaimana didiskusikan sebelumnya dalam pengamalan fikih kesehariannya ia lebih cenderung berada pada tipologi tradisionalisme bermazhab ${ }^{89}$ yakni berpegang pada satu mazhab fikih yakni mazhab Syâfiî. Disamping itu ia juga memiliki pola pikir yang berorientasi pada teori-teori kemaslahatan ${ }^{90}$ sehingga jika dikembalikan pada teori besar tipologi, disamping termasuk dalam tipologi tradisionalisme, Asywadie Syukur juga masuk dalam tipologi modernisme. ${ }^{91}$

Dikatakan dalam bahasa lain bahwa Asywadie Syukur memiliki tipologi yang beragam atau bercampur. Hal seperti ini dipandang biasa karena dalam diri setiap manusia terkadang memiliki pola pikir yang beragam. Oleh karena itu tidak mengherankan pula jika di antara gaya berpikir Asywadie Syukur ini ada yang terkesan tekstual dan ketat, ada pula yang terlihat kontekstual. Hal ini boleh jadi dipengaruhi berbagai faktor seperti lingkungan, tempat, kondisi, dan dunia akademik yang digelutinya bahkan termasuk juga perbedaan masalah yang dihadapi. ${ }^{92}$

68. Begitu juga Imam Mâlik menolak keinginan khalifah Abû Ja'far al-Manshûr menjadikan kitab al-Muwâthâ' sebagai institusi negara yang wajib dipatuhi, sementara Imam Mâlik berpikir masih banyak lagi hadis Nabi yang tersebar dan bisa jadi ada yang lebih kuat dari yang dihimpunnya. Lihat Abû Zahrah, Mâlik: Hayâtuhû wa 'Ashrû Arâ’uhû wa Fiqhuhû (Mesir: al-I'timâd, t.t.), h. 190.

${ }^{87}$ Salah satu sikap dari generasi milennial adanya kecederungan untuk tidak terikat pada salah mazhab, aliran atau pemikiran tertentu sehingga tampak sulit untuk menentukan mazhab yang diikutinya. Hal ini terjadi bisa jadi karena referensi yang digunakan, guru yang mengajarkan atau karena kurang mengerti. Bandingkan dengan Noorhaidi Hasan, "Menuju Islamisme Populer," dalam Noorhaidi Hasan (ed.), Literatur Keislaman Generasi Melenial: Trasmisi, Apropriasi dan Kontestasi (Yogyakarta: Pascasarjana UIN Sunan Kalijaga Press, 2018), h. 18-25.

${ }^{88}$ Jasser Auda, Maqasid al-Shari'ah as Philosophy of Islamic A System Approach (London: The International Institut of Islamic Thought, 2008), h. 164. Lihat juga secara umum karya Mhd. Syahnan, Contemporary Islamic Legal Discourse (Medan: IAIN Press, 2010); Mhd. Syahnan, Hukum Islam dalam Bingkai Transdisipliner (Medan: Perdana Publishing, 2018).

${ }^{89}$ Ibid., h. 162.

${ }^{90}$ Ibid., h. 176.

${ }^{91}$ Ibid., h. 162 dan 168.

${ }^{92}$ Dalam teori sosiologi pengetahuan disebutkan bahwa sebuah pemikiran tidak muncul dari ruang hampa, melainkan ada latar belakang yang mempengaruhi dalam pembentukan pemikiran itu. Lihat Karl Mannheim, Ideologi dan Utopia: Menyingkap Kaitan Pemikiran dan Politik, terj. F. Budi Hardiman (Yogyakarta: Kanisius, 1991), h. 3-4. 
Jika dilihat dari gaya Asywadie Syukur dalam menetapkan hukum Islam, posisi Asywadie Syukur tampaknya lebih cenderung sebagai mujtahid tarjîhî. Hal ini menunjukkan bahwa Asywadie Syukur tidak ingin melepaskan diri dari ulama walaupun sangat dimungkinkan ia dapat mengkaji persoalan hukum secara mandiri. Keterikatan pada pendapat ulama menunjukkan bahwa ia tidak mengabaikan ulama pendahulu justru sikap ini juga menunjukkan bahwa ia lebih mengutamakan ketersambungan pendapat dengan para ulama yang diakui keilmuan dan kesalehannya.

Namun pada persoalan-persoalan tertentu terutama pada persoalan yang tidak ditemukan adanya kajian ulama terdahulu atau pada persoalan yang tergolong baru termasuk persoalan lokalitas, ia menganalisis dan mengkaji berdasarkan metode-metode hukum yang telah dirumuskan para ulama. Sikap ambil bagian dalam mengkaji hukum ini menunjukkan Asywadie Syukur bisa berada lebih tinggi dari tingkat sebelumnya yaitu sebagai mujtahid fíal-masâ'il. ${ }^{93}$

\section{Penutup}

Pendapat-pendapat yang dikemukakan Asywadie Syukur khususnya dalam tulisan ini sebenarnya adalah persoalan-persoalan yang pernah difatwakan para ulama sebelumnya termasuk pula pada persoalan lokalitas. Namun demikian, ciri khas Asywadie Syukur tetap terlihat ketika ia mengemukakan pendapat-pendapat ulama sebelumnya baik dalam memberikan dukungan atau ketika ia mengkritik atau tidak menyetujui suatu pemikiran. Ia selalu menyertakan argumentasi yang berlandaskan dalil dan keilmuan dalam ushul fikih. Inilah yang menjadi ciri khas Asywadie Syukur dalam menanggapi suatu persoalan hukum.

Dalam menanggapi suatu persoalan hukum, pertama kali yang dilakukannya adalah kembali pada al-Qur'an sebagai dasar membangun pemikiran yang selanjutnya menggunakan hadis Nabi sebagai pendukung dan penguat. Setelah menggunakan kedua sumber ini, Asywadie Syukur menggunakan metode qawlî. Namun tidak cukup hanya sampai di sini, ia juga menyertai kajiannya dengan metode manhajî. Beberapa metode manhajî yang digunakan Asywadie Syukur adalah metode muqâranah, tarjîh, takhyîr dan kaidah-kaidah ushûlî baik lughawiyah atau pun ma'nawiyah seperti qiyâs, istihsân, 'urf, mashlahah dan maqâshid al-syarî‘ah. Disamping itu, Asywadie Syukur juga menggunakan kaidah-kaidah fikih untuk mendukung hasil kajiannya.

Jika dilihat dari kecenderungan bermazhab, Asywadie Syukur sepertinya mengikuti mazhab Syâfi'î walaupun tampak juga terbuka terhadap mazhab yang lain. Dilihat dari

\footnotetext{
${ }^{93} \mathrm{Di}$ antara ulama ada yang membagi tingkatan mujtahid ke dalam mujtahid muthlaq dan mujtahid muqayyad. Mujtahid muqayyad terbagi kepada mujtahid fi al-madzhab, fi al-masầil, fì altakhrîj dan fì al-tarjîh. Syukur, Mode Ijtihad, h. 6-7. Lihat juga Nâdiah Syarîf al-'Umarî, al-Ijtihâd fí al-Islâm: Ushûluhû, Ahkâmuhû, Âfâtuhû (Beirut-Lebanon: Mu'assasah al-Risâlah, 2001), h. 173-193. Begitu juga Amîr Saî̀d al-Zibarî, Mabâhits fĩ Ahkâm al-Fatwâ (Beirut-Lebanon: Dâr Ibn Hazm, 1995), h. 118-126.
} 
kecenderungan pola pikir tampaknya Asywadie Syukur berada pada tipologi neo-tradisionalisme bermazhab yaitu berpegang pada beberapa mazhab fikih. Namun pengamalan fikih kesehariannya ia lebih cenderung berada pada tipologi tradisionalisme bermazhab yakni berpegang pada satu mazhab fikih yakni mazhab Syâfi'î. Di samping itu ia juga memiliki pola pikir yang berorientasi pada teori-teori kemaslahatan yang termasuk dalam tipologi modernisme. Jika dilihat dari gaya Asywadie Syukur dalam menetapkan hukum Islam, posisi Asywadie Syukur tampaknya lebih cenderung sebagai mujtahid tarjîhî.

\section{Pustaka Acuan}

Al-Albânî, Muhammad Nâshiruddîn. Silsilah al-Ahâdîts al-Shahîhah, Jilid IV. Riyâdh: Makabah al-Ma'ârif, 2000.

Al-Amidî, Saif al-Dîn Abî al-Hasan 'Alî ibn Abî 'Alî ibn Muhammad. al-Ihkâm fî Ushûl alAhkâm, Jilid II, Juz III. Beirut-Lebanon: Dâr al-Fikr, 1996.

Al-Baijûrî, Ibrâhîm. Hâsyiyah al-Syaikh Ibrâhîm al-Baijûrî, Jilid II. t.t.: Dâr al-Fikr, t.t.

Al-Bukharî, Abû 'Abdullâh Muhammad ibn Ismâ'îl. Shahîh al-Bukhârî, Juz V. BeirutDamaskus: Dâr Ibn Katsîr, t.t.

Al-Burnû, Muhammad Shidqî ibn Ahmad. al-Wajîz fî Idhâh Qawấid al-Fiqh al-Kulliyah. Beirut-Lebanon: Mu'assasah al-Risâlah, 1982.

Hilmy, Masdar. "Quo-Vadis Islam Moderat Indonesia? Menimbang Kembali Modernisme Nahdlatul Ulama dan Muhammadiyah," dalam MIQOT: Jurnal Ilmu-ilmu Keislaman, Vol. 36, No. 2, 2012.

Ja'far, Ja'far. "Respons Dewan Fatwa Al Jam'iyatul Washliyah terhadap Isu Akidah dan Syariah di Era Global," dalam al-Manahij: Jurnal Kajian Hukum Islam, Vol. 10, No. $1,2016$.

Ja'far, Ja'far. "Peran Al Jam'iyatul Washliyah dalam Merevitalisasi Madhhab Shafi'i di Era Kontemporer," dalam Justicia Islamica: Jurnal Kajian Hukum dan Sosial, Vol. 13, No. 1, 2016.

Jafar, Jafar. "Al Jam'iyatul Washliyah dan Problem Kepemimpinan Non Muslim dan Perempuan," dalam AHKAM: Jurnal Ilmu Syariah, Vol. 17, No. 2017.

Al-Jauziyah, Ibn al-Qayyim. I Iâm al-Muwaqqi'în an Rabb al-'Âlamîn, Jilid I. Riyâdh: Dâr Ibn al-Jauzî, $1423 \mathrm{H}$.

Al-Jîzânî, Muhammad ibn Husain ibn Hasan. Ma'âlim Ushûl al-Fiqh inda Ahl al-Sunnah wa al-Jamâ'ah. Riyâdh: Dâr ibn Jauzî, 1996.

Al-Nasâ'1̂, Abû 'Abdurrahmân Ahmad ibn Syu'aib. Kitâb al-Sunan al-Kubrâ, Juz VIII. BeirutLebanon: Mu'assasah al-Risâlah, 2001.

Al-Sadlân, Shâlih ibn Ghânim. al-Qawâ'id al-Fiqhiyah al-Kubrâ wamâ Tafarra 'anhâ. Riyâdh: Dâr Balansiah, 1417. 
Al-Salâm, 'Izz al-Dîn ibn 'Abd. Qawâ'id al-Ahkâm fî̀ Mashâlih al-Anâm, Jilid II. BeirutLebanon: Dâr al-Kutub al-'Ilmiyah, 1999.

Al-Shan'ânî, Muhammad ibn Ismâ‘îl al-Amîr. Subul al-Salâm al-Maushilah ilâ Bulûgh alMarâm, Jilid V. Riyâdh: Dâr ibn al-Jauzî, 1421.

Al-Suyûthî, Jalâl al-Dîn. al-Asybâh wa al-Nazhâ'ir. Beirut-Lebanon: Dâr al-Kutub al'Ilmiyah, 1983.

Syahnan, Mhd. Contemporary Islamic Legal Discourse. Medan: IAIN Press, 2010.

Syahnan, Mhd. Hukum Islam dalam Bingkai Transdisipliner. Medan: Perdana Publishing, 2018.

Al-Thabrânî. al-Mu'jam al-Shaghîr li Thabrânî, Jilid I. Beirut-Lebanon: Dâr al-Kutub al'Ilmiyah, 1983.

Al-'Umarî, Nâdiah Syarîf. al-Ijtihâd fî al-Islâm: Ushûluhû, Ahkâmuhû, Afâtuhû. BeirutLebanon: Mu'assasah al-Risâlah, 2001.

Al-Zibarî, Amîr Saî̀d. Mabâhits fî Ahkâm al-Fatwâ. Beirut-Lebanon: Dâr Ibn Hazm, 1995.

Al-Zuhailî, Wahbah. Ushûl al-Fiqh al-Islâmî, Jilid II. Damaskus: Dâr al-Fikr. 2001.

Aminuddin, Abdul Qayyum dan Mohd Anuar Ramli. "Penggunaan Mazhab selain Syâfi'i dalam Fatwa Negara Brunei Darussalam," dalam Jounal of Fatwa Management and Research, Vol. 7, No.1, 2016.

Arifi, Ahmad. "Dinamika Pemikiran Fikih dalam NU: Analisis atas Nalar Fikih Pola Mazhab," dalam Ulumuna, Vol. 13, No. 1, 2009.

Arifi, Ahmad. "Dinamika Fikih Pola Mazhab: Kontekstualisasi Bermazhab dalam Fikih NU," dalam Jurnal Asy-Syir'ah, Vol. 43, No. 1, 2009.

Auda, Jasser. Maqâshid al-Sharî‘ah as Philosophy of Islamic A System Approach. London: The International Institut of Islamic Thought, 2008.

Dahlan, Bayani, et al. H.M. Asywadie Syukur Ulama Kampus dan Ulama Pembangunan. Banjarmasin: Antasari Press, 2007.

Dahlan, Moh. "Moderasi Hukum Islam dalam Pemikiran Ahmad Hasyim Muzadi," dalam al-Ihkam, Vol. 11, No. 2, 2016.

Dakhoir, Ahmad. "Pemikiran Fikih Shaikh Muhammad Arshad al-Banjari," dalam Islamica, Vol. 4, No. 2, 2010.

Elfia. "Ishlah dalam Takharuj Menurut Hanafiyah Versus Ishlah dalam Kompilasi Hukum Islam (Analisis Kebijakan Hukum)," dalam Jurnal Ilmu Syari’ah, Vol. 17, No. 1, 2018.

Haryanto, Rudy. "Bagi Hasil dan Bank Syari'ah (Solusi terhadap Bunga Bank)," dalam Al-Ihkam, Vol. 5, No. 2, 2010.

Hasan, Noorhaidi. "Menuju Islamisme Populer," dalam Noorhaidi Hasan (ed.). Literatur Keislaman Generasi Melenial: Trasmisi, Apropriasi dan Kontestasi. Yogyakarta: Pascasarjana UIN Sunan Kalijaga Press, 2018. 
MIQOT Vol. 43 No. 1 Januari-Juni 2019

Helim, Abdul. Menelusuri Pemikiran Hukum Ulama Banjar Kontemporer. Malang: Intelegensi Media, 2018.

Jum'ah, 'Alî. “al-Niqâb Murthabath bi al-'Âdât," dalam Mahmûd Hamdî Zaqzûq, al-Niqâb 'Adah wa Laisa 'Ibâdah. Kairo: Dâr al-Kutub al-Mishriyah, 2008.

Khallâf, 'Abdul Wahhâb. 'Ilm Ushûl al-Fiqh. Kuwait: Dâr al-Qalam, 1978.

Kudhori, Muhammad. "Kontroversi Hukum Cadar dalam Perspektif Dialektika Syariat dan Adat," dalam Ijtihad Jurnal wacana Hukum dan Keislaman, Vol. 18, No. 1, 2018.

Madkûr, Muhammad Salâm. al-Ijtihâd fî al-Tasyrî‘ al-Islâmî. t.t.: Dâr al-Nahdhah, 1984.

Mahfiana, Layyin. "Konsepsi Kepemilikan dan Pemanfaatan Hak atas Tanah Harta Bersama antara Suami dan Istri," dalam Bauana Gender, Vol. 1, No. 1, 2016.

Mallâh, Husain Muhammad. al-Fatwâ: Nasy'atuhâ wa Tathawwuruhâ-Ushûluhâ wa Tathbîqâtuhâ. Beirut: al-Maktabah al-'Ashriyah, 2001. Jilid II.

Mannheim, Karl. Ideologi dan Utopia: Menyingkap Kaitan Pemikiran dan Politik. terj. F. Budi Hardiman. Yogyakarta: Kanisius, 1991.

Masyhuri, Aziz. Masalah Keagamaan NU. Surabaya: PP RMI dan Dinamika Press, 1997.

Musa, Kamal Fiqry. "Islamic Jurisprudence and Human Rights: At-Takhyîri Approach in Marriage Law," dalam International Conference on Law and Justice: Advance Social science, Education and Humanities Research, Vol. 162, 2017.

Nasir, Muhammad. "Resistensi Ulama Dayah Aceh Tamiang terhadap Hak-Hak Perempuan dalam KHI," dalam MIQOT: Jurnal Ilmu-ilmu Keislaman, Vol. 41, No. 1, 2017.

Niam, Khoirun. "Nahdlatul Ulama and the Production of Muslim Intellectuals in the Beginning of 21st Century Indonesia," dalam Journal of Indonesian Islam, Vol. 11, No. 2, 2017.

Nuwairah, Nahed. "Hak dan Kewajiban Warga Negara Menurut Asywadie Syukur". Tesis. IAIN Antasari Banjarmasin, 2007.

Ritzer, George dan Douglas J. Goodman. Teori Sosiologi Modern. terj. Alimandan. Jakarta: Prenada Media Group. 2004.

Syukur, Asywadie. Mode Ijtihad Masa Dulu dan Masa Kini. Banjarmasin: IAIN Antasari Banjarmasin, 1992.

Syukur, Asywadie. Konsultasi Masalah Hidup dan Kehidupan. Nasrullah (ed.), et al. Banjarmasin: Pusat Pengkajian Islam Kalimantan IAIN Antasari Banjarmasin, 2002. Jilid I.

Syukur, Asywadie."Konsep Harta Perpantangan dan Ishlah Menurut Syekh Muhammad Arsyad al-Banjari". kumpulan makalah VI, tidak diterbitkan.

Syukur, Asywadie. "Riba dan Bunga Bank". Kumpulan makalah VII, tidak diterbitkan.

Syukur, Asywadie. "Kesetaraan Pria dan Wanita Menurut Pandangan Islam". Kumpulan makalah IV, tidak diterbitkan. 
Syukur, Asywadie. "Pengetian Fi Sabilillah sebagai Salah Satu Asnaf Zakat". Kumpulan makalah II, tidak diterbitkan.

Syukur, Asywadie. "Hukum Wanita Haidh Membaca dan Menulis Ayat al-Qur'an dalam Ujian”. Kumpulan makalah II, tidak diterbitkan.

Taslim. "Hukum Bunga Bank Menurut K.H. M. Asywadie Syukur dan K.H. Husin Naparin (Studi Komparasi Pemikiran Hukum Islam)". Tesis. IAIN Antasari Banjarmasin, 2006.

Thanthawî, Muhammad Sayyid. "Wajh al-Mar'ah laisa bi 'Aurah al-Niqâb'Âdah lâ 'Tbâdah," dalam Mahmûd Hamdî Zaqzûq, al-Niqâb 'Adah wa laisa 'Ibâdah. Kairo: Dâr alKutub al-Mishriyah, 2008.

Zahrah, Abû. Al-Syafiî̀ Hayâtuhû wa 'Ashrû Arâ'uhû wa Fiqhuhû. t.t.: Dâr al-Fikr al-'Arabî, 1978.

Zahrah, Abû. Mâlik: Hayâtuhû wa 'Ashrû Arâ'uhû wa Fiqhuhû. Mesir: al-I'timâd, t.t.

Zahro, Ahmad. Tradisi Intelektual NU: Lajnah Bahtsul Masa'il 1926-1999. Yogyakarta: LKiS, 2004.

Zaqzûq, Mahmûd Hamdî. al-Niqâb 'Âdah wa laisa 'Ibâdah. Kairo: Dâr al-Kutub alMishriyah, 2008. 